\title{
POLYPHENOL CONTENTS OF SKIN-CONTACT FERMENTED WHITE WINES
}

\author{
Zs. BENE*a and M. KÁLLAY ${ }^{\mathrm{b}}$ \\ ${ }^{\mathrm{a}}$ Institute of Marketing and Tourism, Faculty of Economics, University of Miskolc H-3515 Miskolc, \\ Egyetemváros. Hungary \\ ${ }^{\mathrm{b}}$ Department of Oenology, Faculty of Horticulture, Szent István University, H-1118 Budapest, Ménesi út 45. \\ Hungary
}

(Received: 27 April 2019; accepted: 23 June 2019)

\begin{abstract}
Skin-contact fermented white wines, the so-called orange or qvevri wines, have been gaining international attention from winemakers, importers, sommeliers, consumers, and journalists over the last 10 years. Sommeliers are now regularly pairing orange wines with fine cuisine. This new culinary trend is part of a general move by the consumer wishing to respect the existence of traditions and innovation, combined with a growing interest in environmental awareness and healthy options. Orange wines are made from white grapes using ancient Georgian techniques. The essence of this method is the long skin-contact fermentation in amphorae without any chemicals or specific yeast. In our work, the polyphenol content of orange wines, in particular total polyphenol and catechin content, as well as colour intensity were measured to ensure safe winemaking technology without oxidized components.
\end{abstract}

Keywords: polyphenol, orange wines, trends in winemaking

Georgia unquestionably owns the roots of winemaking called the Kakhetian, Kartuli, or qvevri method.

In 2013, the qvevri technique was inscribed on the UNESCO Representative List of Intangible Cultural Heritage of Humanity (UNESCO, 2013), and since then many winemakers in Europe (Italian, Slovenian, Spanish, Hungarian) have tried this special technique. The essence of the method is the clay/amphora/qvevri vessel (Fig. 1), in which both alcoholic fermentation and further aging happen. The volume of the qvevris ranges from 2-3 litres to 6-8 thousand litres, but 10-15-thousand-litre qvevris have also been made. In the South Caucasus, the role of the quevri in winemaking is as important as ever (CHICHUA, 2009). According to the Kartuli method, there is a spontaneous fermentation without using specific yeast, using only the indigenous yeast flora in various sized qvevris buried in the ground. It is a long and slow process. The technique has found followers in Italy (Friuli-Venezia Giulia Wine Region), Slovenia, and Croatia, but in recent years also in Romania, Hungary, Spain, France, Chile, Australia, Oregon, and California. Thus, the winemaking method changes according to countries and winemakers. Some new practitioners do not use clay pots or qvevries, but so-called concrete eggs or spin barrel with specific yeasts, too (BonNÉ, 2018).

Two very important facts should be emphasized: one is the use of the natural grape without chemical treatments; the second is letting micro-oxidization happen through the vessel, which gives a special colour similar to "orange" and a unique rich taste, which is unusual in white wines (BENE \& PISKóTI, 2017). Both the Kartuli qvevri wines (white or red)

\footnotetext{
* To whom correspondence should be addressed.

Phone:+36 30903 8448; fax:+36 47396 017; e-mail: bene.zsuzsanna@uni-miskolc.hu
} 
and those made using the new innovative techniques are produced with very long skin contact (BARISASHVILI, 2011). Currently a global trend in winemaking is to minimize chemical treatments and use low intervention (DiAZ et al., 2013).

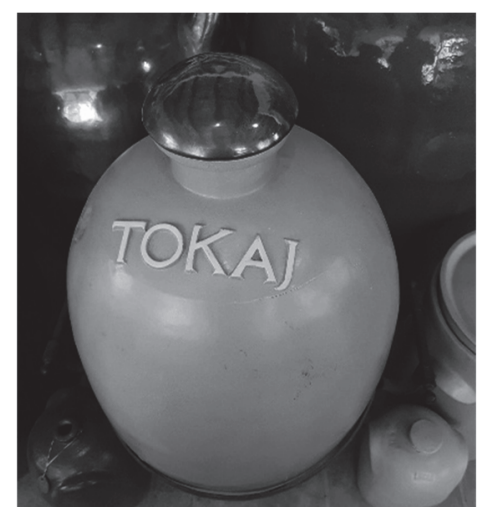

Fig. 1. Amphorae in Legli Pottery in Hungary (Szőlőskislak)

Grape berries have a rich polyphenol content. Phenolic compounds are responsible for the oxidation of wines, and their presence is essential for developing the character of the wine. The composition of phenolic substances varies with grape cultivar, maturation, ecological parameters, oenological and viticultural practices (SINGLETON, 1982). Some of these plant-related compounds, namely flavonoids, have valuable health-promoting effects as antioxidants, anticarcinogens, antivirals, antimicrobials, anthelminthics, and antihormonals (DE BEER et al., 2002). Flavonoid phenols and catechin compounds help with lipid oxidization, have a beneficial effect on the digestive system, and can destroy bacteria in mouth, thus stopping plaque on teeth (LUGASI \& HóvÁRI, 2002). Red wines have a higher quantity of antioxidants than white ones as the result of their phenolic content (LANDRAULT et al., 2001). Within polyphenols, resveratrol can be identified as a preventive compound against cardiovascular diseases (BERTELLI, 2007). Resveratrol can be found in the seed and the skin of the grape. Thus, it can be found in higher amounts in long-macerated and skin-contact white wines (GUERRERo et al., 2010).

As a result of the method used, the total polyphenol content of qvevri wines is higher than that of normal white wines (SHALASHVILI et al., 2011; RosSETTI \& BoselLi, 2017).

In Hungary, qvevri wines from Pinot gris, Tramini, Hárslevelü, Zéta, Cserszegi füszeres, and Rhine riesling are available on the market; they are typically fresh, non-aged wines with roasted and vanilla characters. Both the traditional quevri method and the innovative way are used (BENE \& PisKóti, 2017).

In our previous work, the main characteristic features of Hungarian skin-contact fermented white wines were collected, which are the following:

- The raw materials come from biodynamic viticulture.

- The naturalness is very important. Winemakers strive to use no more than a small amount of sulphur in the process, and the use of physical and chemical stabilizing agents is kept to a minimum or eliminated completely. In this way, environmental consciousness - one of the most important current consumer trends - exists in this winemaking method.

- $\quad$ Orange wines are currently a fashionable product in gastronomy.

Acta Alimentaria 48, 2019 
- $\quad$ These wines are totally dry or semi-dry with high alcohol content.

- They often have an extremely high price.

- Sensory characteristics like vanilla, roasted seeds, peanuts, orange peel, and pear are very important elements.

- The orange colour is not as fundamental as we thought, because there are certain grape varieties, such as Tramini and Pinot gris, which have more colour compounds in the berry skin and can reach a more intensive "orange" colour, but these are not as fruity as those varieties with less colour.

- There are two types of orange wines: one is fresh with fruity aromas and flavours, while the other is more structured and combined with roasted characters.

We considered making our own orange wine and doing the analytical work on the above parameters. The present paper has three objectives:

i) to make a normal white wine and an orange wine from the same lot and variety of biodynamically cultivated grapes and to compare analytical composition;

ii) to measure the quantity of the most important phenolic compounds (catechins, resveratrol, quercetins, proanthocyanidins);

iii) to analyse two original Georgian qvevri wines and compare them with the Hungarian experimental wines.

\section{Materials and methods}

\subsection{Processing method of the Georgian quevri wines}

The grapes are harvested in late autumn in ripe or overripe condition. Picked but not crushed, they are placed into amphoras that allow water and air through their walls. Larger pores are blocked by making the inside of the qvevri water repellent using beeswax. This also makes cleaning the qvevri easier, as bacteria cannot settle in smaller cracks, while at the same time the smallest pores are left open, thus allowing the wine to breathe. There is a long period of soaking on the grape and of fermentation, in which this micro-oxidation has an important part. Following fermentation, the wine remains on the skin at a temperature of $12-14{ }^{\circ} \mathrm{C}$. The autolysis of the yeast plays a positive role in this process. The first racking takes place after 1-2 months, the lees, pulp, and sometimes whole berries are pressed, then placed back in the amphora to mature, thus beginning the long period of conditioning and maturing. Approximately one year later it is bottled without any filtering or treatment.

\subsection{Winemaking methods: normal and quevri Zéta}

Pilot scale conventional fermentation was carried out in a stainless-steel tank; the Kakhetian wine was made in amphora from Légli Pot Manufacture (Fig. 2). The Zéta grape variety was selected, because it had been biodynamically cultivated. Zéta, one of the six permitted grape varieties in the Tokaj Wine Region, is a cross of the Furmint and Bouvier grape varieties, created to promote the formation of noble rotted berries. Thus, it is not a widespread grape variety but an important autochthon one.

In the traditional method for the making of white wine, the steps were as follows: grape processing, must handling, pressing, and fermentation. We used specific yeast (Saccharomyces cerevisiae UVAFERM 228, Lallemand) for the Normal Zéta (NZ). In the case of the Qvevri Zéta wine (QZ), the following steps were performed: destemming, putting into the amphora for 5 weeks for fermentation, pressing, and putting back into the amphora for aging. 


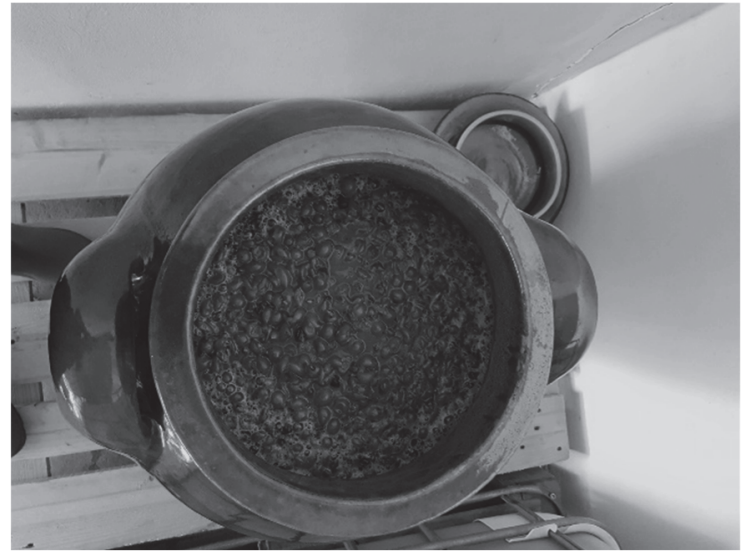

Fig. 2. Skin-contact fermenting Zéta in amphora

The experiment was started with $230 \mathrm{~kg}$ of grapes that were picked at dawn, thus avoiding warming up. They were delivered in crates and afterwards separated into $80 \mathrm{~kg}$ and $150 \mathrm{~kg}$ lots. The $80 \mathrm{~kg}$ lot was picked through with the help of the crusher-destemmer, was filled by hand into the 73-litre amphora, and was placed in a room used for wine storage at a temperature of $15^{\circ} \mathrm{C}$.

The second item $(150 \mathrm{~kg})$ was treated with sulphur powder. After crushing and destemming, the decantation of the must took place using enzyme treatment, followed by pressing and an appliance of yeast as well as sulphuric acid treatment at a controlled temperature $\left(10{ }^{\circ} \mathrm{C}\right)$. We achieved a $72 \%$ juice gain, applying the pressure of 2 bars and placing it in a 100-litre vat.

The qvevri lot was not cooled and no yeast was added. It fermented till there was no residual sugar (5 weeks), and the process was followed with an analytical examination. During fermentation the marc base was submerged every 5 days with constant stirring in the meantime. A traditional manual pressing followed, and the result was placed in the 56-litre amphora instead of the 73-litre due to the loss that resulted from pressing, in addition to what the amphora had absorbed.

The second lot fermented for 10 days, with the regular addition of nutrient salts (twice) in order to provide a steady rate of nutrition. It was racked twice then settled and filtered at the end of February. The lot that was placed in the amphora was not bottled.

\subsection{Analytical measurements - basic parameters}

- Alcohol content: according to Alcolyzer-IR: R2001 published by the Organisation Internationale de la Vigne et du Vin (OIV, 2018)

- Reducing sugar content: according to OIV-MA-AS311-03: R2003 published by OIV (2018)

- Titratable acid content: according to OIV-MA-AS313-01: R2015, 5.2. chapter published by OIV (2018)

- Volatile acid content: according to OIV-MA-AS313-02: R2015 published by OIV, (2018) 


\subsection{Analytical measurements - polyphenols}

- Colour intensity: $\mathrm{A}_{420 \mathrm{~nm}}$, Spectrophotometric method, $1 \mathrm{~cm}$ pathlength cuvette, according to OIV-MA-AS2-07B:R2009 published by OIV (2018)

- Total polyphenol content: according to OIV-MA-AS2-10: R2009 with Folin-Ciocalteu reagent, calibrated to gallic acid, published by OIV (2018)

- Catechin content: $\mathrm{A}_{520 \mathrm{~nm}}$, Spectrophotometric method according to TANNER and BRUNNER (1979), in wine diluted with alcohol and reagent with vanillin

- Total Antioxidant Status: colorimetric measurement, with RANDOX test, Cat. No NX2332. measuring range $0.21-2.94 \mathrm{mmol} \mathrm{l}^{-1}$

- Proanthocyanidins: by method of SwaIN and HiLLIs (1959)

- $\quad t$-resveratrol content: HPLC method developed by KÁLLAY and TöRÖK (1997)

HPLC-instrument: HP Series 1050, column: LiChrospher ${ }^{\circledR} 100, \mathrm{CN}(250 \times 4 \mathrm{~mm} \times 5$ $\mu \mathrm{m})$, detector: HP Series 1050, liquid flow rate: $2 \mathrm{ml} \mathrm{min}^{-1}$, temperature: $30^{\circ} \mathrm{C}$, wavelength: $306 \mathrm{~nm}$, eluent: 5:5:90 = acetonitrile:methyl alcohol:water

- Quercetin: HPLC technique according to CARERI and co-workers (2003)

- $\quad$ pH: according to OIV-MA-AS313-15:R2011 published by OIV (2018)

The analytical measurements were repeated three times in all cases, and the data were processed statistically using IBM SPSS Statistics Software for Windows, Version 23.0, Armonk, NY: IBM Corp.

\section{Results and discussion}

\subsection{Alcohol, sugar, titratable acid, and volatile acid contents}

The measured values can be seen in Table 1.

Table 1. Basic parameters of normal and quevri Zéta wines

\begin{tabular}{lcccc}
\hline Technology & $\begin{array}{c}\text { Alcohol } \\
(\% \mathrm{vol})\end{array}$ & $\begin{array}{c}\text { Reducing sugar } \\
\left(\mathrm{g} \mathrm{l}^{-1}\right)\end{array}$ & $\begin{array}{c}\text { Titratable acid } \\
\left(\mathrm{g} \mathrm{l}^{-1}\right)\end{array}$ & $\begin{array}{c}\text { Volatile acid } \\
\left(\mathrm{g} \mathrm{l}^{-1}\right)\end{array}$ \\
\hline Normal Zéta (NZ) & 12.92 & 1.0 & 8.0 & 0.48 \\
Qvevri Zéta (QZ) & 12.20 & 1.9 & 8.5 & 0.68 \\
\hline
\end{tabular}

In both wines, the fermentation was complete, and there was no residual sugar content. Fermentation of the orange Zéta wine (QZ) took place with no help of specific yeast; only the indigenous yeast flora was required to complete the process.

The two techniques did not result in considerable differences in most of the major parameters measured.

There was one deviation in volatile acid content, which was the result of the must and wine handling in the case of Normal Zéta, because of the use of sulphur dioxide treatment, but the volatile acid content measurement was corrected for sulphur. It can be stated that in the amphora and with a long fermentation time without sulphur dioxide it is possible to make wine without the activity of acetic bacteria. 


\subsection{Phenolic compounds}

The measured values can be seen in Figures 3 and 4 .

Normally, white wines have 170-300 $\mathrm{mg} \mathrm{l}^{-1}$ total polyphenol content, red wines 1800 $4000 \mathrm{mg}^{-1}$ (KÁLlaY, 1998). In our case, qvevri Zéta had $1632 \mathrm{mg} \mathrm{l}^{-1}$ value, which is much higher than a normal white wine and close to the amounts in red wines.

In catechin content, the same difference was observed: qvevri Zéta had a higher value. In this aspect, our experimental samples were different.

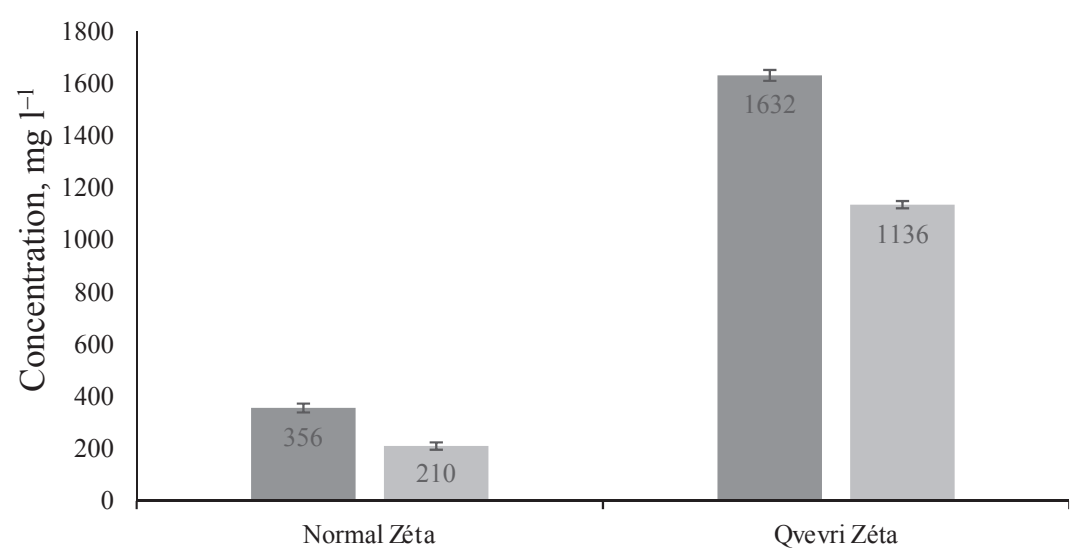

Fig. 3. Total polyphenol and catechin content in normal and qvevri Zéta wines (the error bars are attached on each value range)

Total polyphenol; : catechin

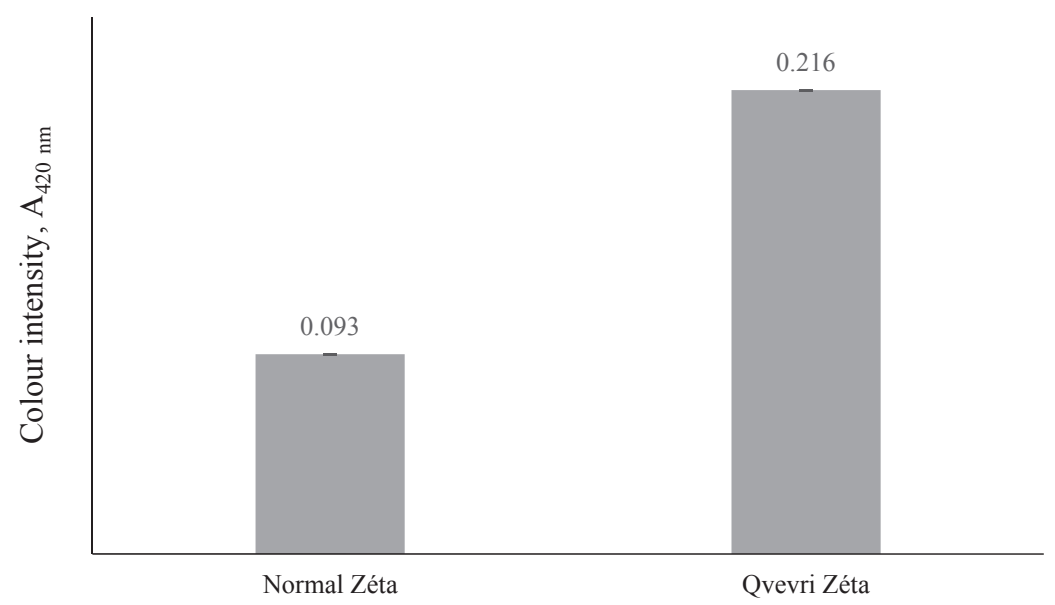

Fig. 4. Colour intensity at $\mathrm{A}_{420 \mathrm{~nm}}$ in normal and qvevri Zéta wines (the error bars are attached on each value range)

In the case of colour intensity, 0.216 value was measured in the case of orange wine, so we had enough compounds that are able to preserve the orange wine without additives, and it is a sign for the consumer that proves the naturalness and the safety of this (type of) method. 


\subsection{Analytical composition of two traditional Georgian quevri wines compared with the Hungarian experimental wines}

The two Georgian quevri wines (Q1, Q2) were made according to the ancient qvevri winemaking method (long, spontaneous fermentation, without sulphur dioxide treatment, fermenting and aging in clay pot). The typical wine type called Kakheti is a white blend of the Rkatsiteli and Mtsvane varieties. Dogi and Gotsa are traditional qvevri wineries in Georgia.

The content of total polyphenols, TAS, proanthocyanidins, catechins, $t$-resveratrol, quercetin, and $\mathrm{pH}$ are shown in Figure 5 and Table 2.

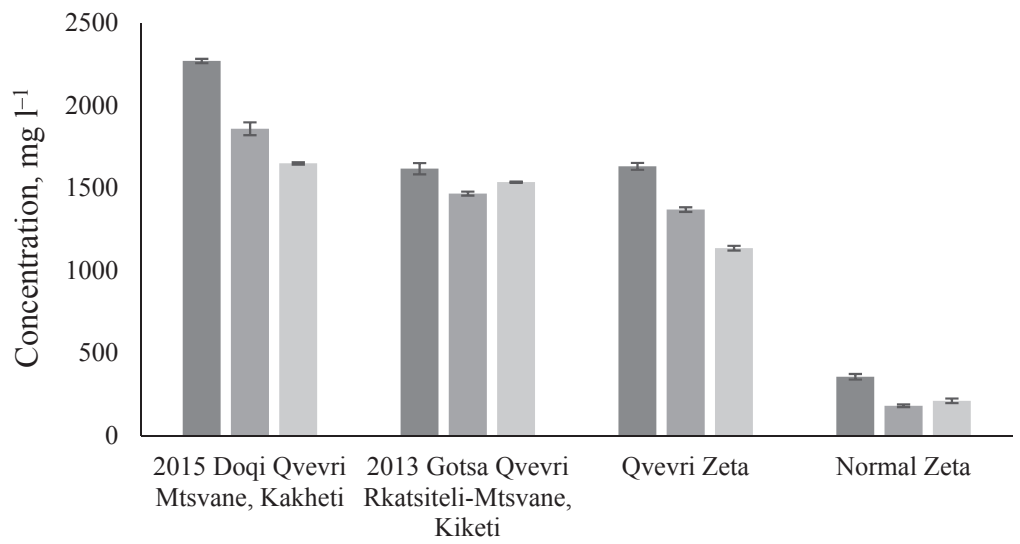

Fig. 5. Comparison of total polyphenolic, proanthocyanidin, and catechin contents of Georgian and Hungarian wines (the error bars are attached on each value range)

: Total polyphenol; : proanthocyanidins; : catechin

Table 2. TAS, $t$-resveratrol, and quercetin contents and $\mathrm{pH}$ of two traditional Georgian qvevri wines and the two Hungarian wine samples

\begin{tabular}{lcccc}
\hline & $\begin{array}{c}\text { Georgian qvevri } \\
\text { wine: 2015 Doqi } \\
\text { Qvevri Mtsvane, } \\
\text { Kakheti (G1) }\end{array}$ & $\begin{array}{c}\text { Georgian qvevri } \\
\text { wine: 2013 Gotsa } \\
\text { Qvevri Rkatsiteli- } \\
\text { Mtsvane, Kiketi } \\
(\mathrm{G} 2)\end{array}$ & $\begin{array}{c}\text { Hungarian qvevri } \\
\text { wine: Qvevri Zéta } \\
\text { (QZ) }\end{array}$ & $\begin{array}{c}\text { Hungarian } \\
\text { conventional wine: } \\
\text { Normal Zéta (NZ) }\end{array}$ \\
\hline $\begin{array}{l}\text { TAS - Total Antioxidant } \\
\left.\text { Status (mmol } ~^{-1}\right)\end{array}$ & 43.1 & 30.7 & 12 & 6.76 \\
$t$-Resveratrol ( $\left.\mathrm{mg} \mathrm{l}^{-1}\right)$ & 0.38 & 1.27 & 1.79 & 1.42 \\
Quercetin ( $\left.\mathrm{mg} \mathrm{l}^{-1}\right)$ & 0.34 & 0 & 0 & 0 \\
$\mathrm{pH}$ & 3.86 & 3.49 & 3.40 & 3.21 \\
\hline
\end{tabular}

Based on the obtained various analytical parameters, the four wines were compared and the differences were statistically evaluated based on the measured values, which are summarized in Table 3.

According to the measured values, it is clear that there were significant differences between the examined wines in five aspects: total polyphenol content, TAS, proanthocyanidins, catechins, and quercetin. In the case of qvevri wines (G1, G2, QZ), the total polyphenol content varied from $1632 \mathrm{mg} \mathrm{l}^{-1}$ up to $2271 \mathrm{mg} \mathrm{l}^{-1}$, which is typical for red wines. 
Table 3. Comparison of the total polyphenol, TAS, proanthocyanidins, catechins, $t$-resveratrol, quercetin and $\mathrm{pH}$ values of the experimental qvevri and normal Zéta wines and the two Georgian qvevri wines

\begin{tabular}{llc}
\hline Chemical components & P-value & Levels of significance \\
\hline Total polyphenol content $\left(\mathrm{mg} \mathrm{l}^{-1}\right)$ & 0.01 & $*$ \\
TAS - Total Antioxidant Status, $\left(\mathrm{mmol} \mathrm{l}^{-1}\right)$ & 0.049 & $*$ \\
Proanthocyanidins $\left(\mathrm{mg} \mathrm{l}^{-1}\right)$ & 0.015 & $*$ \\
Catechins $\left(\mathrm{mg} \mathrm{l}^{-1}\right)$ & 0.013 & $* *$ \\
$t$-Resveratrol $\left(\mathrm{mg} \mathrm{l}^{-1}\right)$ & 0.12 & - \\
Quercetin $\left(\mathrm{mg} \mathrm{l}^{-1}\right)$ & 0.0099 & \\
$\mathrm{pH}$ & 0.86 & \\
\hline
\end{tabular}

Analysis of variance, levels of significance: -: ns; *: $\mathrm{P}<0.05 ; * *: \mathrm{P}<0.01$

The Total Antioxidant Status was 12-43.1 mmol 1-1 in G1, G2, and QZ, which was significantly different from NZ. G1 showed as considerable an amount as found in red wines.

The TAS-value expresses the degree of capturing free radicals as well as how certain food and drinks (in this case wine) can prevent the harmful process of the oxidation of free radicals. The higher the value, the more antioxidants are present that are able to stop oxidation. Free radicals are created due to the natural oxidization processes that take place in the cells under natural conditions. Certain free radicals have an important part in maintaining the normal functioning of organisms, including the regulation of the cell cycle, cell metabolism, and defensive mechanisms. Free radicals are reactive oxygen-, nitrogen-, sulphur-, or carboncentred molecules and particles that have unpaired electrons, making them aggressive with a short lifespan, as they readily engage in chemical reactions with other compounds in order to gain electrons (CADENAS, 1989). Antioxidants are molecules that are able to considerably decrease or even obstruct the oxidation of free radicals (KALT et al., 1999).

According to the available literature, the Riesling grape variety contains the highest quantity of procyanidins of white grape varieties followed by Chardonnay, whereas Mtsvane contains much lower levels of individual and total procyanidins (KHANAL \& HowARD, 2009). In G1, G2, and QZ, considerable values were measured that are similar to Chardonnay in the available literature. It can be explained with the technique and the length of the skin contact.

The catechin content of the quevri wines (G1, G2, QZ) and the normal white wine (NZ) were compared as well. According to the ANOVA, there was significant difference between the investigated wines.

The $t$-resveratrol content was particularly remarkable, because, beside being high in red grapes, in the case of grape varieties from Tokaj it was higher than is usual in other wine regions in both our normal wine and our qvevri Zéta. The reason can be found in the activity of Botrytis cinerea in the late harvest and in the overripe fruit (KÁLlAY \& TÖRÖK, 1997). Normally this value is $1-3 \mathrm{mg} \mathrm{l}^{-1}$ in Tokaj, and these values were higher than values measured in Georgian qvevri wines (G1, G2).

In terms of quercetin content, there was a strongly significant difference between the wines. We found the presence of this component only in G1.

The $\mathrm{pH}$ varied from 3.21 to 3.86. The difference was not significant, but the normal Zéta (NZ) was a more acidulous wine than G1. Normally, wines from the Tokaj Wine Region have 
higher acid content because of the volcanic soil, and the acidity can be preserved during fermentation in the amphora, too.

\section{Conclusions}

These results give us additional information and knowledge on skin-contact fermented white wines. Qvevri white wines have higher polyphenol content than normal white wines, nearly the same as red wines. These wines have little ecological footprint because of the minimal use of wine treatments. In this present study, a normal and a qvevri method Zéta wine were compared. The analytical composition of two Georgian qvevri wines were also compared with the Hungarian ones. For total polyphenol and catechin content, Qvevri Zéta proved to be similar to the majority of the Georgian cultivars.

\section{References}

BARISASHVILI, G. (2011): Making wine in qvevri-a unique Georgian tradition. Available at https://www.qvevriproject. org/resources (Last accessed: 14.04.2018)

Bene, Zs. \& PisKóti, I. (2017): Assessment of orange wines in the light of new food consumption trends. Journal of Food Investigation, 63(4), 1804-1810.

Bertelli, A.A.E. (2007): Wine, research and cardiovascular disease: Instructions for use. Atherosclerosis, 195(2), $242-247$.

Bonné, J. (2018): The insider's guide to orange wine. Available at https://punchdrink.com/articles/insiders-guidebest-orange-wine/ (Last accessed: 09.04.2019)

Cadenas, E. (1989): Biochemistry of oxygen-toxicity. Annu. Rev. Biochem., 58(1), 79-110.

Careri, M., Corradini, C., Elviri, L., Nicoletti, I. \& Zagnoni, I. (2003): Direct HPLC analysis of quercetin and trans-resveratrol in red wine, grape, and winemaking by-products. J. Agr. Food Chem., 51, 5226-5231.

Chichua, D. (2009): Production of wine in qvevri - History, description and analysis. Available at https://kvevri.org (Last accessed: 29.04.2018)

De Beer, D., Joubert, E., Gelderblom, W.C.A. \& Manley, M. (2002): Phenolic compounds: A review of their possible role as in vivo antioxidants of wine. S. Afr. J. Enol. Vitic., 23(2), 48-61.

Diaz, C., Laurie, V.F., Molina, A.-M., Bücking, M. \& Fisher, R. (2013): Characterization of selected organic and mineral components of quevri wines. Am. J. Enol. Vitic., 64, 532-537.

Guerrero, R.F., Puertas, B., Fernandéz, M.I., Piñeiro, Z. \& Cantos-Villar, E. (2010): UVC-treated skin-contact effect on both white wine quality and resveratrol content. Food Res. Int., 43, 2179-2185.

Kalt, W., Forney, C.F., Martin, A. \& Prior, R.L. (1999): Antioxidant capacity, vitamin C, phenolics, and anthocyanins after fresh storage of small fruits. J. Agr. Food Chem., 47, 4638-4644.

KÁllay, M. (1998): Borászati kémia (Chemistry of winemaking). -in: EperJesi, I., Kállay, M. \& MaGYar, I. (1998): Borászat (Winemaking). Mezőgazda Kiadó, Budapest, pp. 253-430.

KÁllaY, M. \& TöRÖK, Z. (1997): Determination of resveratrol isomers in Hungarian wines. Kertészeti Tudomány, 29(3-4), 78-82.

KHANAL, R.C. \& Howard, L.R. (2009): Procyanidin composition of selected fruits and fruit by-products is affected by extraction method and variety. J. Agr. Food Chem., 57, 8839-8843.

Landrault, N., Poucheret, P., Ravel, P., Gasc, F., Cros, G. \& Teissedre, P.L. (2001): Antioxidant capacities and phenolic levels of French wines from different varieties and vintages. J. Agr. Food Chem., 49, 3341-3348.

Lugasi, A. \& Hóvári, J. (2002): Flavonoid aglycons in foods of plant origin II. Fresh and dried fruits. Acta Alimentaria, 31, 63-71.

OIV (2018): Compendium of international methods of analysis of wines and musts, 2nd volume. Available at http:// www.oiv.int/en/technical-standards-and-documents/methods-of-analysis/compendium-of-internationalmethods-of-analysis-of-wines-and-musts-2-vol (Last accessed:23.06.2019)

Rossetti, F. \& Boselli, E. (2017): Effects of in-amphorae winemaking on the chemical and sensory profile of Chardonnay wine. Scientia Agriculturae Bohemica, 48(1), 39-46. 
Shalashvili, A., Ugrekhelidze, D., Targamadze, I., Zambakhidze, N. \& Tsereteli, L. (2011): Phenolic compounds and antiradical efficiency of Georgian (Kakhethian) wines. J. Food Sci. Eng., 1, 361-365.

Singleton, V.L. (1982): Grape and wine phenolics: background and prospects. Wine Centennial Symposium, Proceedings of the University of California, Davis, USA, pp. 215-227.

SwaIn, T. \& Hillis, W.E. (1959): The phenolic constituents of Prunus domestica. I. The quantitative analysis of phenolic constituents. J. Sci. Food Agr., 10, 63-68.

TANner, H. \& Brunner, H.R. (1979): Getränke-analytik. Verlag Heller Chemie und Verwaltungsgesellschaft GmbH, Germany, pp. 57-61.

UNESCO (2013): Ancient Georgian traditional Qvevri winemaking method. 8.COM, Available at https://ich.unesco. org/en/RL/ancient-georgian-traditional-qvevri-winemaking-method-00870 (Last accessed: 29.04.2018)

Open Access statement. This is an open-access article distributed under the terms of the Creative Commons Attribution 4.0 International License (https://creativecommons.org/licenses/by/4.0/), which permits unrestricted use, distribution, and reproduction in any medium, provided the original author and source are credited, a link to the $\mathrm{CC}$ License is provided, and changes - if any - are indicated. (SID_1) 